\title{
AGRONOMIC CHARACTERISTICS OF 'PRATA-ANÃ' AND 'MAÇÃ' BANANAS MICROPROPAGATED ${ }^{1}$
}

\author{
LUÍS HENRIQUE MARIANO SCANDELAI ${ }^{2}$, SARITA LEONEL ${ }^{3}$, LUCIENE MICHELLE APPONI ${ }^{2}$
}

\begin{abstract}
The experiment evaluated the agronomic characteristics of 'Prata-anã' and 'Maçã' banana plants, in the São Manuel region of São Paulo state. In the first crop cycle, the number of days from planting to inflorescence and from inflorescence to harvest; the number of shoots until the appearance of inflorescence and during the harvest period; active leaves number at inflorescence appearance and during the harvest period. Were evaluated yield parameters: like average weight of bunch, hand, rachis and fruit; average fruit number per hand and bunch; average fruit diameter and length. Incidences of plague diseases, as well as their severity were also evaluated. Delineation was totally at random, with 2 treatments, 15 replications and 5 useful plants per experimental plot. Both cultivars were characterized by values of descriptive average statistics and standard deviation, for characteristic interests. Number of days from planting to harvest was similar for both 'Prata-anã' and 'Maçã', 574 and 567 days respectively. Banana plants showed good phytosanitary quality throughout the whole cycle.
\end{abstract}

Index terms: Banana, Musa spp, micropropagation, cycle.

\section{DESEMPENHO AGRONÔMICO DE BANANEIRAS 'PRATA-ANÃ E 'MAÇ̃̃' MICROPROPAGADAS}

RESUMO - O experimento foi instalado com o objetivo de estudar o desempenho agronômico de cultivares de bananeira Prata-anã e Maçã, na região de São Manuel-SP. Foram avaliadas as seguintes características de desenvolvimento, no primeiro ciclo de produção: número de dias do plantio à floração e da mesma à colheita, número de rebentos (filhos) emitidos até o surgimento da inflorescência e na época da colheita, número de folhas ativas na época do aparecimento da inflorescência e da colheita, e características de rendimento, como peso médio do cacho, ráquis, penca e fruto, número médio de frutos por penca e cacho, comprimento e diâmetro médio dos frutos. Também foi avaliada a incidência de pragas e doenças. Foi empregado o delineamento inteiramente casualizado, com 2 tratamentos, 15 repetições e 5 plantas úteis por parcela experimental. As duas cultivares foram caracterizadas pelos valores das estatísticas descritivas, média e desvio-padrão, para as características de interesse no experimento. Foram estabelecidas possíveis correlações entre medidas de desenvolvimento e produção. As duas cultivares apresentaram ciclo do plantio até a colheita de 574 dias para 'Prata-anã' e 567 dias para 'Maçã', sendo que o ciclo produtivo foi maior na 'Prata-anã'. Não houve problemas de pragas e doenças em todo o ciclo de produção, nas duas cultivares avaliadas.

Palavras-chave: Banana, Musa spp, micropropagação, ciclo cultural.

Banana plant is classified as Musa spp. The most important sub-group and cultivar are Gros Michel (Gros Michel), Cavendish (Nanica, Nanicão), Prata (Prata, Pacovan e Maçã), Terra (Terra, D’Angola), among others.

The state of São Paulo is responsible for about 18\% (Agrianual, 2004 ) of the total yield of national bananas. Historically, the traditional producing region of bananas on coastland and in Ribeira Valley is responsible for $95 \%$ of the states production. However, the producers of Paulista Plateau have showed higher interest in this culture as a way to diversify their activity (Rangel et al., 1998), but some answers, about the agronomic performance like growth and yield of banana plants in these regions are unknown, showing a necessity for researching, which may give useful results to the banana producers. Works which compare some regions of banana produces in the state of Minas Gerais are reported by Pereira et al., (1998), in Jaíba (Northern State) and Salomão et al. (1998) in Visconde do Rio Branco (Minas Gerais - Zona da mata) and concluded that 'Prata-anã' in no irrigated condition presented a cycle of 411 and 520 days respectively, although in different edapho-climatic conditions when compared to regions within the state of São Paulo.

Since 1985, producers of banana planting material have used the micropropagation process, however there are few reports about phenological characteristics of this type of planting material in the field. Up to now there have been citations about an increase (Fachinello et al., 1996) or decrease (Teixeira 2000) of the banana cycle when this kind of planting material is used. According to Álvares \& Caldas (2002) when conventional sprouts present physiologic and sanitary quality, it is possible to obtain the same yield as with the micropropagated materials planted. The same way, Pereira et al. (1998) only found significant differences between kinds of propagation materials for shoot variable, however the types of planting material (sword suckers, rhizome sections and tissue culture) did not influence the pseudostem diameter, bunch and fruit weight, number of fruit/bunch and crop cycle.
The purpose of this research was to evaluate the agronomic, physiological, sanitary, and productive characteristics of 'Prata-anã' and 'Maçã' banana plants, micropropagated, in edapho-climatic conditions in the São Manuel region of the state of São Paulo, Brazil.

The experiment was installed in the São Manuel Experimental Farm, which belongs to the Agronomy School of UNESP located in the coordinates $22^{\circ} 44^{\prime}$ latitude $\mathrm{S}, 48^{\circ} 34^{\prime}$ longitude W, at $740 \mathrm{~m}$ of altitude.

Delineation was totally at random, with 2 treatments, 15 replications and 5 useful plants per experimental plot. Eight fruits per bunch were used for sampling the post-harvest evaluations. Both cultivars were characterized by values of average descriptive statistics and standard deviation, for agronomic characteristics. The planting material was originated from micropropagation in a laboratory and acclimatized in a greenhouse, on dischargeable trays, using industrialized substrate.

The transplanting of planting material from dischargeable trays to black plastic bags ( 5 liter) was done in September/2001, and then they were acclimatized in the greenhouse. Planting was done in January/2002. The holes were: $40 \mathrm{~cm}$ deep $\mathrm{x} 40 \mathrm{~cm}$ wide $\mathrm{x} 40 \mathrm{~cm}$ long. The space between plants was $2.5 \mathrm{~m}$ and between lines $2,5 \mathrm{~m}$, resulting in $6.25 \mathrm{~m}^{2} /$ plant. The fertilizer used for each hole was made up of $200 \mathrm{~g}$ of calcareous, 15 liters of cow manure, $100 \mathrm{~g}$ of phosphate and $15 \mathrm{~g}$ of potassium chloride.

The fertilizer was made after a soil analysis and following a Technical Bulletin $n^{\circ} 100$ from IAC (Raij et al.,1997). Foliar analysis was done to detect the nutritional state of the banana plant and the $3^{\text {rd }}$ leaf from top to bottom was used for sampling (Borges et al. 1997). Proposed characteristics to evaluation were divided into three main categories to better understand the results. The categories were organized in chronological order: plant cycle, and growth and production characteristics. In the first category, concerning the plant cycle, two characteristics were evaluated: number of days from planting to inflorescence and length of cycle from inflorescence to harvest.

\footnotetext{
${ }^{1}$ (Trabalho 013/2005). Recebido: 13/01/2005. Aceito para publicação: 23/02/2006.

${ }^{2}$ Eng $^{\circ}$ Agr $^{\circ}$. Bolsista da FAPESP. UNESP/Faculdade de Ciências Agronômicas/Botucatu.

${ }^{3}$ Prof ${ }^{a}$ Dr ${ }^{\mathrm{a}}$. UNESP. Depto de Produção Vegetal. FCA/Botucatu/SP. CEP 18603-970. sarinel@fca.unesp.br.
} 
TABLE 1 - Results for development cycle of banana plants 'Prata-anã' and 'Maçã' - São Manuel/SP, 2003.

\begin{tabular}{|c|c|c|c|c|c|}
\hline \multicolumn{6}{|c|}{ Cycle (days) } \\
\hline Cultivar & $\begin{array}{l}\text { Vegetative } \\
\text { Average }\end{array}$ & \multicolumn{2}{|c|}{ Productive } & \multicolumn{2}{|c|}{ Total } \\
\hline Maçã & 435 & 132 & 27 & 567 & 33 \\
\hline
\end{tabular}

TABLE 2 - Average weight of bunch, hand, rachis and fruit. São Manuel/SP, 2003.

\begin{tabular}{ccccccccc}
\hline \multicolumn{8}{c}{ Hand $(\mathrm{Kg})$} & \multicolumn{2}{c}{ Rachis $(\mathrm{g})$} & \multicolumn{2}{c}{ Fruit $(\mathrm{g})$} \\
\hline Cultivar & Average & St.Dev. & Average & St.Dev. & Average & St.Dev. & Average & St.Dev. \\
\hline Maçã & 7,81 & 1,08 & 1,21 & 0,16 & 780 & 162,1 & 99,3 \\
Prata-anã & 8,14 & 1,22 & 1,16 & 0,16 & 861,3 & 189,3 & 94,1 & 11,52 \\
\hline
\end{tabular}

TABLE 3 - Average number of fruit per hand and hand per bunch. São Manuel/SP, 2003.

\begin{tabular}{|c|c|c|c|c|}
\hline \multirow{2}{*}{ Cultivar } & \multicolumn{4}{|c|}{ Average number } \\
\hline & \multicolumn{2}{|c|}{ Fruit/Hand } & \multicolumn{2}{|c|}{ Hand/bunch } \\
\hline Maçã & 12,20 & 0,48 & 6,10 & 0,57 \\
\hline
\end{tabular}

TABLE 4 - Diameter and length of fruit. São Manuel SP, 2003.

\begin{tabular}{ccccc} 
& \multicolumn{2}{c}{ Average diameter $(\mathrm{cm})$} & \multicolumn{2}{c}{ Average length $(\mathrm{cm})$} \\
\cline { 2 - 5 } Cultivar & Average & $\begin{array}{c}\text { Standard } \\
\text { deviation }\end{array}$ & Average & $\begin{array}{r}\text { Standard } \\
\text { Deviation }\end{array}$ \\
\hline Maçã & 3,60 & 0,22 & 11,60 & 0,57 \\
Prata-anã & 3,50 & 0,20 & 11,30 & 0,80 \\
\hline
\end{tabular}

Average height of plants until inflorescence were analyzed and the average diameter of pseudostem was monthly evaluated at 20 $\mathrm{cm}$ height, with a pachymeter. Average leaf number was evaluated up to harvest period as well as the average number of suckers. The postharvest evaluations were grouped as production characteristics: bunch weight, hand number, fruit number per hand, fruit and hand weight, rachis weight, diameter and length of fruit.

The results obtained on the research are showed on the tables 1, 2, 3 and 4 and the figures 1, 2, 3 and 4. According to Prezotti (1992), the foliar analyses showed that the values were adequate or close to it, and the banana plants showed good phytosanitary quality in the whole cycle, not damaging the growth and yield.

According to the results showed on Table 1, plant cycle was divided in: vegetative, productive and total periods. It was observed that the number of days from planting to harvest was similar for both cultivar, 574 and 567 days, to 'Prata-anã' and 'Maçã' respectively. The productive cycle of 'Prata-anã' was higher than 'Maçã'.

Also, Foltran et al. (1998) studied the same cultivars in the western region of São Paulo state, with conventional planting material, and concluded that 633 days were the total cycle in nonirrigated conditions, probably because of the micropropagated planting material that is more uniform (Drew \& Smith, 1990 and Vuylsteke \& Ortiz, 1996) when compared to the others.

A possible answer to cycle delay for these cultivars was climatic factors, mainly low temperature and precipitation. There were ten months (between January 2002 and August 2003) with minimum average temperature lower than $15^{\circ} \mathrm{C}$. According to Borges et al., (1997) under $15^{\circ} \mathrm{C}$ the plant activity is nule and the longer its duration the more prolonged its effect on the cycle. In 2002 it was obtained $1,076.5 \mathrm{~mm}$ of precipitation and less than 1,200 mm.year ${ }^{-1}$, the environment is considered borderline and banana crop only survives and fructifies if the planted clone was resistant to nonirrigated condition or if the irrigation practice is used (Borges et al. 1997). In 2003, until August, 872 mm were accumulated.

The diameter of the pseudostem, plant height, leaf and suckers number were showed in Figures 1, 2, 3 and 4, respectively. The cultivar Prata-anã showed higher stem diameter and plant height in all cycle, although the production characteristics were very similar. In spite of the cultivar, the leaf and the suckers number showed variable results according to the months evaluated. 'Prata-anã' showed higher leaf number from Jan/02 to Jan/03 and 'Maçã' showed this in the following two months. Leaf number decreased between inflorescence and harvest period for both cultivars. As vegetative cycle was shorter for'Prata-anã', this cultivar resulted with lower leaf number from January/2003 on. The same happened with pseudostem diameter, leaf number and plant height.

Also 'Prata-anã' showed heavier bunches, even though 'Maçã' had showed higher weight of hand and bigger fruits. However a higher number of hand per bunch was obtained for 'Prata-anã'. The active leaf number on harvest period was similar for both cultivars; it did not showed possible correlation with bunch weight, differently from the results obtained by Gaiva et al., (1996). The cultivar Prata-anã

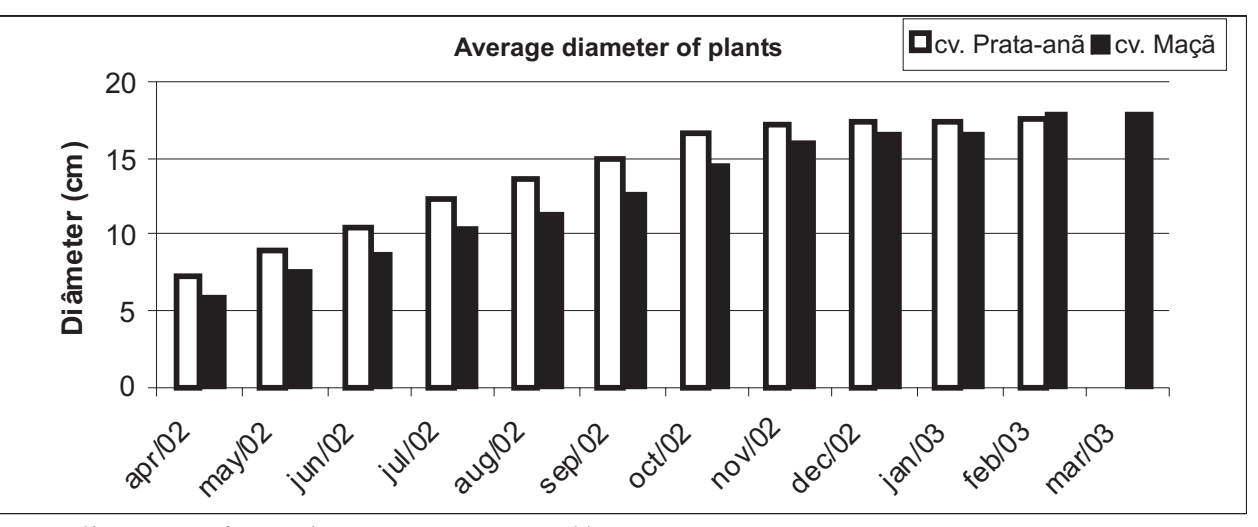

FIGURE 1 - Results for average diameter of pseudostem, São Manuel/SP, 2003. 


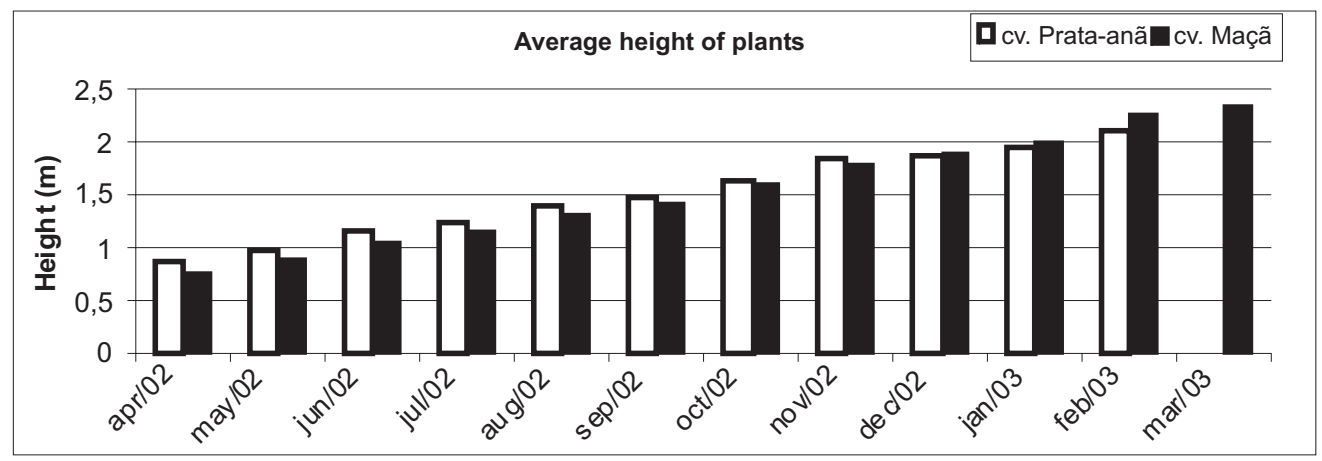

FIGURE 2 - Results for average height of plants, São Manuel SP, 2003.

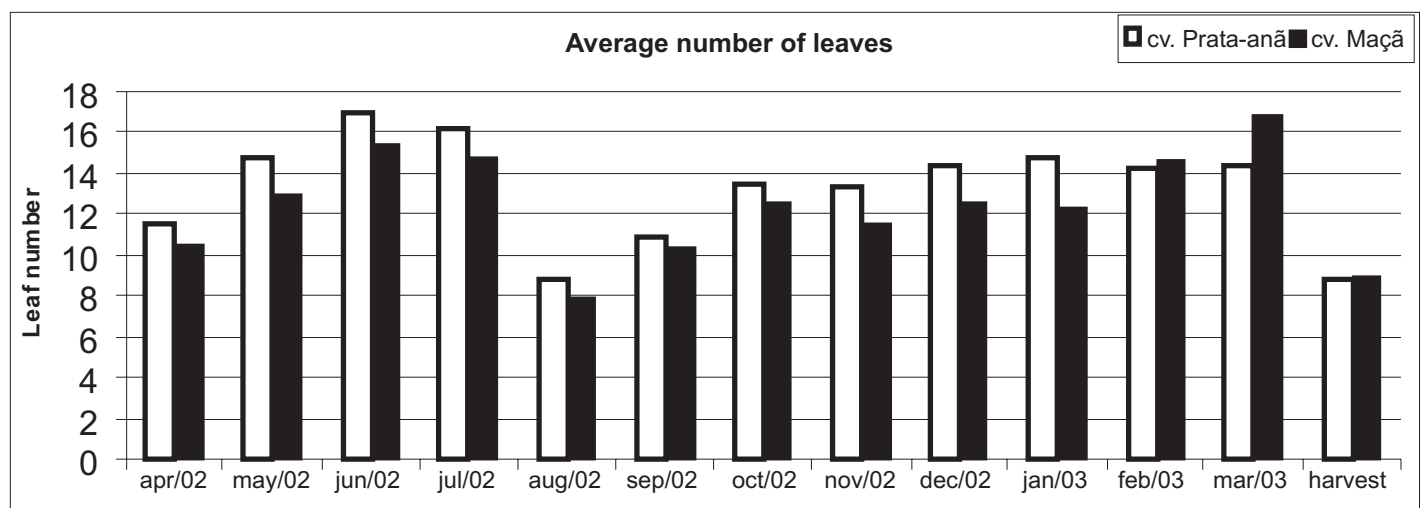

FIGURE 3 - Results for average number of leaves until harvest, São Manuel/SP, 2003.

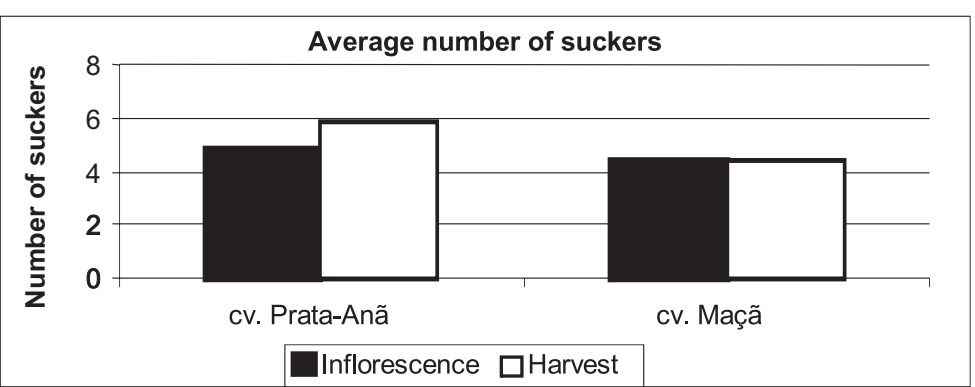

FIGURE 4 - Average number of suckers obtained in the experiment, São Manuel/SP, 2003.

presented higher active leaves number during almost the whole cycle and showed heavier bunches, it could be made a possible correlation with these characteristics evaluated.

By studying the characteristics of matrix plants of 'Fartavelhaco' (AAB), 'Mysore' (AAB) and 'Nanicão' (AAA) banana plant cultivars, Gaiva et al. (1996) observed that higher active leaf number at the harvest period referred of heavier bunches for 'Mysore' and 'Nanicão' cultivars. These results are in agreement with the results showed in the present research, with the cultivar Prata-anã.

Day number from planting to harvest was similar for both 'Prataanã' and 'Maçã', 574 and 567 days respectively. Although 'Prata-anã' showed heavier bunches, 'Maçã' showed higher hand weight and bigger fruits. However, higher number of hand per bunch was obtained with 'Prata anã'.

\section{REFERENCES}

AGRIANUAL 2004: anuário da agricultura brasileira. São Paulo: FNP Consultoria \& Agroinformativos, 2004. p.169.

ÁLVARES, M. do C.; CALDAS, L. S.; Crescimento, produção e variação somaclonal em bananeiras micropropagadas. Pesquisa Agropecuária Brasileira, Brasília, v.37, n.3, p. 415-420, 2002.

BORGES, A.L.; ALVES, E.J.; SILVA, S.de O e; SOUZA, L. da S.; MATOS, A.P. de, FANCELLI, M.; OLIVEIRA, A.M.G.; CORDEIRO, Z.J.M.; SILVEIRA, J.R.S.; COSTA, D. da C.; MEDINA, V.M.; OLIVEIRA, C.O. de. O cultivo da banana. Cruz das Almas: EMBRAPA-CNPMF, 1997. 109p. (Circular Técnica, 27).
DREW, R.A.; SMITH, M.K. Field evaluation of tissue cultured bananas in South-Eastern Queensland. Australian Journal of Experimental Agriculture, Collingwood,v.30, n.4, p.569-574, 1990.

FACHINELLO, J.C., NACHTIGAL, J.C., KERSTEN, E. Fruticultura: fundamentos e práticas. Pelotas: Universitária-UFPEL, 1996.311p.

FOLTRAN, D.E.; TEIXEIRA, L.A.J.; PIRES, R.C de; ZAMARIOLLI, E.R. Comportamento de sete cultivares de bananeira no Oeste Paulista. In: CONGRESSO BRASILEIRO DE FRUTICULTURA, 15., 1998. Poços de Caldas-MG. Resumos... Lavras: UFLA/SBF, 1998. p.127.

GAIVA, H.N.; RUGGIERO, C.; PERECIN, D.; BARBOSA, J.C. Estudo de correlações entre características de desenvolvimento e produção de três cultivares de bananeira. In: CONGRESSO BRASILEIRO DE FRUTICULTURA, 14., 1996, Curitiba-PR. Resumos... Londrina: IAPAR, 1996. p.77.

PEREIRA, M.C.T.; SALOMÃO, L.C.C.; SILVA, S. de O.; SEDIYAMA, C.S.; COUTO. F.A.D.A., SILVA NETO,S.P. da. Crescimento e produção de primeiro ciclo da bananeira (Musa spp.) 'Prata-anã' (AAB) em sete espaçamentos em Jaíba-MG. In: CONGRESSO BRASILEIRO DE FRUTICULTURA, 15., 1998. Poços de CaldasMG. Resumos... Lavras: UFLA/SBF, 1998, p.130.

PREZOTTI, L.C. Recomendações de calagem e adubação para o Estado do Espírito Santo. 3 aproximação. Vitória: EMCAPA, 1992. 73p.

RAIJ, B. V.; CANTARELLA, H.; QUAGGIO, J.A.; FURLANI, A.M.C. Recomendações de adubação e calagem para o Estado de São Paulo. 2.ed. Campinas: Instituto Agronômico, 1997. 285p.

RANGEL, A., PENTEADO, L.A.C., TONET, R.M. Cultura da banana. Campinas: CATI, Departamento de Comunicação e Treinamento, 1998.66p.

SALOMÃO, L.C.C.; PEREIRA, M.C.T.; SEDIYMA, C.S.; COUTO, F.A.D.A Crescimento e produção de primeiro ciclo de bananeira (Musa spp.) 'Prata-anã' em sete espaçamentos, em Visconde do Rio Branco-MG. In: CONGRESSO BRASILEIRO DE FRUTICULTURA, 15., 1998. Poços de Caldas-MG. Resumos... Lavras: UFLA/SBF, 1998. p.131.

TEIXEIRA, L.A. Bananeira (Musa spp). In: MELETTI, L.M.M(Coord.). Propagação de frutíferas tropicais. Guaíba: Agropecuária, 2000. p.105-124.

VUYLSTEKE, D.; ORTIZ, R. Field performance of conventionalvs. In vitro propagules of plantain (Musa spp., AAB group). HortScience, Alexandria, v.31, n.5, p.862-865, 1996. 